\title{
ANALISIS PENGELOLAAN ALOKASI DANA DESA (ADD) DI KECAMATAN MARE KABUPATEN BONE
}

\author{
M. Ridwan Tikollah ${ }^{1}$, M. Yusuf A. Ngampo ${ }^{2}$ \\ ${ }^{1}$ Pendidikan Akuntansi Universitas Negeri Makassar \\ Email: m.ridwan.tikollah@unm.ac.id \\ ${ }^{2}$ Pendidikan Akuntansi Universitas Negeri Makassar \\ Email: yusufngampo@gmail.com
}

\begin{abstract}
The research is aimed to detemine the management of Alokasi Dana Desa (ADD) in Mare Subdistrict Bone Regency. which include: planning, implementation, administration, reporting, dan accountability. The population of this research were all Village Government and its apparatus and accountability report of APBDes Mare Subdistrict Bone Regency a number of 17 villages. The sample of the study was chosen by purposive sampling with the criteria: (1) the village receiving the highest $\mathrm{ADD},(2)$ the village receiving the lowest $\mathrm{ADD},(3)$ the village located in the capital city of Mare Subdistrict, (4) the nearest village of the capital city of Mare Subdistrict, and (5) the farthest village from the capital city of Mare Subdistrict. Based on the criteria, five villages were chosen: Batu Gading Village, Data Village, Mario Village, Lappa Upang Village, and Kadai Village. The data were collected by questionnaire and documentation. The data obtained were analyzed using descriptive-comparative method with percentage of crude index agreement (indeks kesesuaian kasar/IKK). The results of this research suggest that the management of ADD which includes: planning, implementation, administration, reporting, and accountability with 63 indicators in Mare Subdistrict Bone Regency has been in accordance with Peraturan Menteri Dalam Negeri Nomor 113 Tahun 2014 tentang Pengelolaan Keuangan Desa.
\end{abstract}

Keywords: ADD, Pengelolaan Keuangan Desa

\begin{abstract}
Abstrak: Penelitian ini bertujuan untuk mengetahui pengelolaan ADD di Kecamatan Mare Kabupaten Bone. yang meliputi: perencanaan, pelaksanaan, penatausahaan, pelaporan, dan pertanggungjawaban. Populasi penelitian ini adalah seluruh Pemerintah Desa beserta aparatnya dan laporan pertanggungjawaban APBDes di Kecamatan Mare Kabupaten Bone sejumlah 17 desa. Sampel penelitian dipilih secara purposive sampling dengan kriteria: (1) Desa yang menerima dana ADD tertinggi, (2) Desa yang menerima dana ADD terendah, (3) Desa yang letaknya di Ibu Kota Kecamatan, (4) Desa yang letaknya terdekat dari Ibu Kota Kecamatan Mare, dan (5) Desa yang letaknya terjauh dari Ibu Kota Kecamatan Mare. Berdasarkan kriteria tersebut dipilih lima desa, yakni: Desa Batu Gading, Desa Data, Desa Mario, Desa Lappa Upang, dan Desa Kadai. Pengumpulan data dilakukan dengan kuesioner dan dokumentasi. Data yang diperoleh dianalisis menggunakan metode deskriptif-komparatif dengan persentase indeks kesesuaian kasar (IKK). Hasil penelitian menunjukkan bahwa pengelolaan ADD yang meliputi: perencanaan, pelaksanaan, penatausahaan, pelaporan, dan pertanggungjawaban dengan 63 indikator di Kecamatan Mare Kabupaten Bone telah sesuai dengan Peraturan Menteri Dalam Negeri Nomor 113 Tahun 2014 tentang Pengelolaan Keuangan Desa.
\end{abstract}

Kata Kunci: ADD, Pengelolaan Keuangan Desa

\section{PENDAHULUAN}

Salah satu dampak positif dari otonomi daerah adalah terjadinya perubahan sistem pemerintahan dari sistem sentralistik ke sistem desentralistik. Desentralisasi dalam otonomi daerah berarti ada pelimpahan wewenang dari pemerintah pusat ke pemerintah daerah. Pelimpahan wewenang tersebut berarti 
pemberian kewenangan dan keleluasaan kepada daerah untuk mengelola dan memanfaatkan sumber daya daerah secara optimal. Meskipun titik berat otonomi diletakkan pada tingkat Kabupaten/Kota, namun secara esensi sebenarnya kemandirian tersebut harus dimulai dari level pemerintahan di tingkat paling bawah, yaitu Desa. Berdasarkan Pasal 1 UndangUndang Nomor 6 Tahun 2014 tentang Desa menyebutkan bahwa: "Desa adalah kesatuan masyarakat hukum yang memiliki batas wilayah yang berwenang untuk mengatur dan mengurus urusan pemerintahan, kepentingan masyarakat setempat berdasarkan prakarsa masyarakat, hak asal usul, dan/atau hak tradisional yang diakui dan dihormati dalam sistem pemerintahan Negara Kesatuan Republik Indonesia.”

Sehubungan dengan hal tersebut, untuk menyelenggarakan otonomi daerah tentunya desa memerlukan kewenangan dan kemampuan untuk mencari sumber keuangan sendiri dan didukung dengan bantuan keuangan dari pusat dan daerah. Keuangan desa pada dasarnya merupakan subsistem dari keuangan negara. Berdasarkan pasal 71 Undang-Undang Nomor 6 tahun 2014 tentang Desa menyebutkan bahwa "keuangan desa adalah semua hak dan kewajiban desa yang dapat dinilai dengan uang serta segala sesuatu baik berupa uang maupun barang yang berhubungan dengan pelaksanaan hak dan kewajiban desa."

Salah satu sumber keuangan desa yang diatur dalam Undang-undang desa adalah ADD. Berdasarkan Pasal 1 Peraturan Menteri Dalam Negeri Nomor 113 Tahun 2014 tentang Pengelolaan Keuangan Desa menyebutkan bahwa "ADD adalah dana yang diberikan kepada desa yang berasal dari dana perimbangan keuangan pemerintah pusat dan daerah yang diterima oleh kabupaten/kota setelah dikurangi Dana Alokasi Khusus."

Berdasarkan Pasal 1 Peraturan Bupati Bone Nomor 13 Tahun 2015 tentang Tata Cara Pembagian Dana Transfer Desa "dana transfer adalah dana yang bersumber dari Dana Desa, Dana Bagi Hasil, Pajak dan Retribusi Daerah, ADD, dan Bantuan Keuangan yang ditransfer ke rekening Pemerintah Desa." Selanjutnya dalam Pasal 2 Peraturan Bupati Bone Nomor 13 Tahun 2015 tentang Tata Cara Pembagian Dana Transfer Desa, dikemukakan bahwa "tujuan pembagian dana transfer untuk membiayai penyelenggaraan pemerintahan desa dalam melaksanakan pelayanan pemerintahan, pembangunan dan kemasyarakatan." Sehingga melalui ADD desa berpeluang meningkatkan pelayanan pemerintahan, pembangunan, dan kemasyarakatan.

Untuk mewujudkan tujuan peraturan perundangan tersebut, dana transfer haruslah dikelola dengan tahapan yang sesuai Pasal 93 Peraturan Pemerintah Nomor 43 Tahun 2014 tentang Peraturan Pelaksanaan Undang-Undang Nomor 6 Tahun 2014 tentang Desa, yang meliputi: perencanaan, pelaksanaan, penatausahaan, pelaporan, dan pertanggungjawaban. Untuk melaksanakan ketentuan pasal tersebut, dalam Bab V Peraturan Menteri Dalam Negeri Nomor 113 Tahun 2014 tentang Pengelolaan Keuangan Desa dijelaskan bahwa:

1. Perencanaan pengelolaan keuangan desa dalam bentuk APBDesa berdasarkan RPJMDesa dan RKDesa tahun berkenaan disusun oleh Sekertaris Desa dan disampaikan kepada Kepala Desa yang kemudian dibahas bersama dengan Badan Permusyawaratan Desa untuk sepakati bersama dalam musyawarah yang melibatkan masyarakat paling lambat bulan oktober tahun berjalan.

2. Pelaksanaan pengelolaan keuangan desa, penerimaan dan pengeluaran desa dalam rangka pelaksanaan kewenangan desa dilaksanakn melalui rekening desa yang harus didukung oleh bukti yang lengkap dan sah. Serta pelaksanaan kegiatan dengan dokumen Rencana Anggaran Biaya yang mengharuskan mengajukan Surat Permintaan Pembayaran.

3. Penatausahaan dilakukan oleh bendahara desa, dengan kewajiban mencatat setiap penerimaan dan pengeluaran serta melakukan tutup buku setiap akhir bulan secara tertib dan menyampaikan laporan pertanggungjawabannya kepada Kepala Desa.

4. Pelaporan pelaksanaan APBDesa di sampaikan Kepala Desa kepada Bupati berupa laporan semeter pertama paling lambat akhir bulan Juli tahun berjalan dan laporan semester akhir tahun paling lambat akhir bulan Januari tahun berikutnya.

5. Pertanggungjawaban realisasi pelaksanaan APBDesa terdiri dari pendapatan, belanja, dan pembiayaan dengan melampirkan format Laporan Pertanggungjawaban Realisasi Pelaksanaan APBDesa, format Laporan Kekayaan Milik Desa, dan format Laporan Pemerintahan dan Pemerintah 
Daerah yang masuk ke desa yang harus diinformasikan kepada masyarakat secara tertulis dan dengan media informasi.

Menindaklajuti peraturan perundangan tersebut, Pemerintah Kabupaten Bone telah merealisasikan kebijakan pemberian ADD kepada setiap desa. Pemerintah Kabupaten Bone mengeluarkan Peraturan Bupati Bone Nomor 14 Tahun 2015 tentang Besaran Dana Transfer pada setiap desa di Kabupaten Bone.

Salah satu kecamatan yang ada di Kabupaten Bone yang telah mendapatkan realisasi dari kebijakan tersebut adalah Kecamatan Mare yang terdiri dari 17 desa. Berdasarkan hasil observasi, diketahui beberapa fakta pada pengelolaan Dana Alokasi Desa (ADD) di Kecamatan Mare Kabupaten Bone, yaitu:

1. Pada tahap perencanaan, Sekertaris Desa menyusun Rancangan Peraturan Desa tentang APBDesa berdasarkan RKPDesa dengan melakukan musyawarah yang melibatkan Kepala Desa, Badan Permusyarawatan Desa dan masyarakat, namun keterlibatan masyarakat sangat minim serta penyusunan yang terlambat sehingga tidak disepakati pada tahun berjalan.

2. Pada tahap pelaksanaan, dalam pengajuan pelaksanaan pembayaran Sekertaris Desa tidak meneliti kelengkapan pembayaran yg diajukan pelaksana kegiatan dan menguji kebenaran perhitungan tagihan atas bebab APBDesa yang tercantum dalam permintaan pembayaran, sehingga pengajuan permintaan pembayaran tetap terpenuhi walaupun tidak memenuhi persyaratan.

3. Pada tahap penatausahaan, Bendahara Desa seringkali terlambat melakukan tutup buku setia akhir bulan, sehingga penyampaian kepada Kepala Desa ikut terlambat.

4. Pada tahap pelaporan, Kepala Desa diharuskan menyampaikan laporan realisasi pelaksanaan APBDesa, berupa laporan semester pertama disampaikan paling lambat akhir bulan Juni tahun berjalan dan laporan semester akhir tahun disampaikan paling lambat akhir bulan Januari tahun berikutnya. Namun pada kenyataannya laporan semester pertama seringkali terlambat.

5. Pada tahap pertanggungjawaban, Kepala Desa menyampaikan laporan pertanggunjawaban realisasi pelaksanaan APBDesa kepada Bupati setiap akhir tahun yang terdiri dari pendapatan, belanja, dan pembiayaan degan ikut melampirkan format Laporan Pertanggungjawaban APBDesa, Kekayaan Milik Desa dan Laporan Program Pemerintah dan Pemerintah Daerah yg masuk ke desa. Tetapi pada aturan yang mengharuskan Pemerintah Desa menginformasikan laporan pertanggungjawaban kepada masyarakat tidak dilaksanakan.

Beberapa hasil penelitian mengenai pengelolaan ADD di beberapa daerah menunjukkan hasil yang beragam. Penelitian Apriliani (2014) yang bertujuan untuk mengetahui pengelolaan ADD dari tiga tahap yaitu perencanaan, pelaksanaan, dan pertanggungjawaban di Desa Kedungrejo Kecamatan Muncar Kabupaten Banyuwangi tahun 2013 menunjukkan bahwa pada tahap perencanaan, pelaksanaan, dan pertanggungjawaban ADD telah memenuhi prosedur yang berlaku. Namun masalah yang muncul adalah kurangnya koordinasi antar anggota Tim Pelaksana ADD serta penyampaian laporan pertanggungjawaban yang terlambat. Penelitian lain oleh Thomas (2012) yang bertujuan untuk mengetahui pengelolaan ADD dan hambatan-hambatan yang dihadapi oleh pemerintah desa dalam pengelolaan ADD di Desa Sebawang Kecamatan Sesayap Kabupaten Tana Tidung menunjukkan bahwa 30 persen dari dana ADD bisa berjalan sesuai dengan petunjuk namun 70 persen dari ADD berjalan kurang optimal karena lebih direalisasikan pada pembangunan fisik dan pengadaan barang. Hambatan yang dihadapi dalam proses pengelolaan ADD adalah rendahnya sumber daya manusia aparat desa dan kurangnya koordinasi. Penelitian sebelumnya oleh Subranto (2009) yang bertujuan untuk mendeskripsikan akuntabilitas pengelolaan ADD menunjukkan bahwa untuk perencanaan dan pelaksanaan kegiatan ADD sudah menampakkan adanya pengelolaan yang akuntabel dan transparan. Demikian pula dalam pertanggungjawaban dilihat secara hasil fisik sudah menunjukkan pelaksanaan yang akuntabel dan transparan. Namun dari sisi administrasi masih diperlukan adanya pembinaan lebih lanjut, karena belum sepenuhnya sesuai dengan ketentuan. Kendala utamanya adalah belum efektifnya pembinaan aparat pemerintahan desa dan kompetensi sumber daya manusia, sehingga masih memerlukan pendampingan dari aparat pemerintah daerah secara berkelanjutan. 
Berdasarkan hasil observasi dan hasilhasil penelitian tersebut, menarik untuk menganalisis setiap tahapan pengelolaan ADD tersebut mulai dari perencanaan, pelaksanaan, penatausahaan, pelaporan, dan pertanggungjawaban berdasarkan peraturan pengelolaan keuangan desa yang diatur dalam Peraturan Menteri Dalam Negeri Nomor 113 Tahun 2014 tentang Pengelolaan Keuangan Desa yang diimplementasikan oleh Pemerintah Desa di Kecamatan Mare Kabupaten Bone.

\section{TINJAUAN PUSTAKA}

Berdasarkan Pasal 72 Undang Undang Nomor 6 tahun 2014 tentang Desa menyebutkan bahwa, "ADD merupakan bagian dari dana perimbangan yang diterima Kabupaten/Kota dalam anggaran paling sedikit 10 persen setelah dikurangi Dana Alokasi Khusus." Selanjutnya, berdasarkan Pasal 1 Peraturan Menteri Dalam Negeri Republik Indonesia Nomor 113 Tahun 2014 tentang Pengelolaan Keuangan Desa menyebutkan bahwa "ADD selanjutnya disingkat $\mathrm{ADD}$, adalah dana perimbangan yang diterima kabupaten/kota dalam Anggaran Pendapatan dan Belanja Daerah Kabupaten/Kota setelah dikurangi Dana Alokasi Khusus." Sejalan dengan hal tersebut, berdasarkan Pasal 1 Peraturan Bupati Bone Nomor 15 tahun 2015 tentang Pedoman Penyusunan Anggaran Pendapatan dan Belanja Desa menyebutkan bahwa, "ADD yang selanjutnya disingkat ADD, adalah dana perimbangan yang diterima kabupaten dalam Anggaran Pendapatan dan Belanja Daerah Kabupaten setelah dikurangi Dana Alokasi Khusus.” Berdasarkan pengertian di atas dapat disimpulkan bahwa ADD adalah dana yang dialokasikan oleh Pemerintah Kabupaten/Kota untuk setiap desa, yang bersumber dari bagian dana perimbangan keuangan pusat dan daerah yang diterima oleh Pemerintah Kabupaten/Kota dengan jumlah paling sedikit 10 persen.

Mengingat penjelasan atas UndangUndang Nomor 6 Tahun 2014 tentang Desa, bahwa desa mempunyai sumber pendapatan diantaranya adalah ADD yang merupakan bagian dana perimbangan yang diterima Kabupaten/Kota. Sehingga pengelolaan ADD merupakan satu kesatuan dengan pengelolaan keuangan desa. Berdasarkan Pasal 93 Peraturan Pemerintah Nomor 43 Tahun 2014 tentang Peraturan Pelaksanaan Undang-Undang Nomor 6 tahun 2014 menyebutkan bahwa:
1) Pengelolaan keuangan desa meliputi: (a) Perencanaan, (b) Pelaksanaan, (c) Penatausahaan, (d) Pelaporan, dan (e) Pertanggungjawaban;

2) Kepala Desa adalah pemegang kekuasaan pengelolaan keuangan Desa sebagaimana yang dimaksud ayat (1);

3) Dalam melaksanakan kekuasaan pengelolaan keuangan desa sebagaiman dimaksud pada ayat (2), kepala desa menguasakan sebagian kekuasaanya kepada perangkat desa.

Berdasarkan Pasal 1 Peraturan Menteri Dalam Negeri Republik Indonesia Nomor 113 Tahun 2014 tentang Pengelolaan Keuangan Desa menyebutkan bahwa "pengelolaan keuangan desa adalah keseluruhan kegiatan yang meliputi perencanaan, pelaksanaan, penatausahaan, pelaporan, dan pertanggungjawaban keuangan desa." Selanjutnya, Berdasarkan Pasal 1 Peraturan Bupati Bone Nomor 15 tahun 2015 tentang Pedoman Penyusunan Anggaran Pendapatan dan Belanja Desa menyebutkan bahwa "pengelolaan keuangan desa adalah keseluruhan kegiatan yang meliputi perencanaan, pelaksanaan, pelaksanaan, penatausahaan, pelaporan, dan pertanggungjawaban keuangan desa." Dari pengertian di atas dapat disimpulkan bahwa pengelolaan ADD adalah keseluruhan kegiatan yang meliputi tahap perencanaan, pelaksanaan, penatausahaan, pelaporan, dan pertanggungjawaban, dimana Kepala Desa sebagai pemegang kekuasaan dibantu dengan perangkat desa lainnya.

Tahapan pengelolaan keuangan desa tersebut diatur dalam Peraturan Menteri Dalam Negeri Nomor 113 Tahun 2014 tentang Pengelolaan Keuangan Desa sebagai berikut:

1) Perencanaan

Perencanaan ADD diatur dalam Pasal 20 hingga Pasal 23 Peraturan Menteri Dalam Negeri Nomor 113 Tahun 2014 tentang Pengelolaan Keuangan Desa. Berdasarkan pasalpasal tersebut disimpulkan bahwa kegiatan pada tahap perencanaan dalam pengelolaan keuangan desa, meliputi:

a) Sekertaris Desa menyusun Rancangan Peraturan Desa tentang APBDesa berdasarkan RKPDesa tahun berkenaan;

b) Sekertaris Desa menyampaikan kepada Kepala Desa untuk kemudian melakukan Musrembangdes yang melibatkan BPD dan masyarakat untuk disepakati; 
c) Rancangan Peraturan Desa tentang APBDesa disepakati paling lambat bulan oktober tahun berjalan;

d) Rancangan Peraturan Desa tentang APBDesa yang telah disepakati bersama disampaikan oleh Kepala Desa kepada Bupati /Walikota melalui camat paling lambat 3 (tiga) hari sejak disepakati untuk dievaluasi.

2) Pelaksanaan

Pelaksanaan ADD diatur dalam Pasal 24

hingga Pasal 34 Peraturan Menteri Dalam Negeri Nomor 113 Tahun 2014 tentang Pengelolaan Keuangan Desa. Berdasarkan pasalpasal tersebut disimpulkan bahwa kegiatan pada tahap pelaksanaan dalam pengelolaan keuangan desa, meliputi:

a) Semua penerimaan dan pengeluaran desa dilaksanakan melalui rekening desa dengan didukung oleh bukti yang lengkap dan sah;

b) Pengeluaran desa yang mengakibatkan beban APBDesa tidak dapat dilakukan sebelum rancangan peraturan desa tentang APBDesa ditetapkan menjadi peraturan desa;

c) Penggunaan biaya tak terduga terlebih dulu harus dibuat Rincian Anggaran Biaya yang disahkan Kepala Desa;

d) Pelaksanaan kegiatan harus mengajukan Rencana Anggaran Biaya yang diverivikasi oleh Sekertaris Desa dengan meneliti kelengkaan permintaan pembayaran, menguji kebenaran perhitungan tagihan, menguji ketersediaan dana untuk kegiatan yang dimaksud;

e) Berdasarkan Rencana Anggaran Biaya, pelaksana kegiatan mengajukan SPP;

f) Sekertaris Desa harus menolak permintaan pembayaran oleh pelaksana kegiatan apabila tidak memenuhi persyaratan dan apabila memenuhi persyaratan Kepala Desa menyetujui dan bendahara melakukan pembayaran.

3) Penatausahaan

Penatausahaan ADD diatur dalam Pasal

35 dan Pasal 36 Peraturan Menteri Dalam Negeri Nomor 113 Tahun 2014 tentang Pengelolaan Keuangan Desa. Berdasarkan pasalpasal tersebut disimpulkan bahwa kegiatan pada tahap penatausahaan dalam pengelolaan keuangan desa, meliputi:

a) Bendahara desa melakukan pencatatan setiap pengeluaran dan penerimaan menggunakan buku kas umum, buku kas pembantu pajak dan buku bank dan melakukan tutup buku setia akhir bulan secara tertib;

b) Bendahara desa wajib mempertanggungjawabkan uang melalui laporan pertanggungjawaban yang disampaikan setia bulan kepada Kepala Desa paling lambat tanngal 10 bulan berikutnya.

4) Pelaporan

Pelaporan ADD diatur dalam Pasal 37

Peraturan Menteri Dalam Negeri Nomor 113 Tahun 2014 tentang Pengelolaan Keuangan Desa. Berdasarkan pasal tersebut disimpulkan bahwa kegiatan pada tahap pelaporan dalam pengelolaan keuangan desa, meliputi:

a) Sekertaris Desa menyusun laporan semester pertama dan Kepala Desa menyampaikan kepada Bupati/Walikota pada akhir bulan Juni tahun berjalan;

b) Sekertaris Desa menyusun laporan semester akhir tahun dan Kepala Desa menyampaikan kepada Bupati/Walikota paling lambat bulan Januari tahun berikutnya.

5) Pertanggungjawaban

Pertanggungjawaban ADD diatur dalam Pasal 38 hingga Pasal 43 Peraturan Menteri Dalam Negeri Nomor 113 Tahun 2014 tentang Pengelolaan Keuangan Desa. Berdasarkan pasalpasal tersebut disimpulkan bahwa kegiatan pada tahap pertanggungjawaban dalam pengelolaan keuangan desa, meliputi:

a) Sekertaris Desa menyusun laporan pertanggungjawaban yang terdiri dari pendapatan, pengeluaran, dan pembiayaan dengan melampirkan format laporan pertanggungjawaban Realisasi Anggaran Pelaksanaan APBdesa tahun anggaran berkenaan, format Laporan Kekayaan Milik Desa per 31 Desember tahun anggaran berkenaan, dan format Laporan Program emerintah dan Pemerintah Daerah yang masuk ke desa

b) Kepala Desa menyampaikan kepada Bupati/Walikota setiap akhir tahun anggaran melalui Camat paling lambat 1 (satu) bulan setelah akhir tahun anggaran.

c) Laporan realisasi dan laporan pertanggungjawaban realisasi pelaksanaan APBDesa diinformaskan ke masyarakat secara tertulis dan dengan media informasi yang mudah diakses oleh masyarakat.

\section{METODE}

Penelitian ini merupakan penelitian deskriptif kualitatif yang menggambarkan 
pengelolaan ADD berdasarkan Peraturan Menteri Dalam Negeri Nomor 113 Tahun 2014 tentang Pengelolaan Keuangan Desa di Kecamatan Mare Kabupaten Bone. Pengelolaan ADD merupakan keseluruhan tahap kegiatan yang meliputi: perencanaan, pelaksanaan, penatausahaan, pelaporan, dan pertanggungjawaban ADD, dimana Kepala Desa sebagai pemegang kekuasaan pengelolaan keuangan desa dan menguasakan sebagian kekuasaannya kepada perangkat desa. Pengukuran variabel penelitian ini adalah sebagai berikut:

Tabel 1 Pengukuran Variabel

\begin{tabular}{|c|c|}
\hline Tahap Kegiatan & Indikator \\
\hline Perencanaan & $\begin{array}{l}\text { - Sekertaris Desa menyusun Rancangan Peraturan Desa tentang APBDesa } \\
\text { berdasarkan RKPdesa tahun berkenaan. } \\
\text { - Rancangan Peraturan Desa tentang APBDesa disepakati paling lambat } \\
\text { bulan Oktober tahun berjalan. } \\
\text { - Rancangan Peraturann Desa tentang APBDesa yang telah disepakati } \\
\text { bersama disampaikan oleh Kepala Desa kepada Bupati/Walikota melalui } \\
\text { Camat paling lambat } 3 \text { (tiga) hari sejak disepakati untuk dievaluasi. }\end{array}$ \\
\hline Pelaksanaan & $\begin{array}{l}\text { - Semua penerimaan dan pengeluaran desa dilaksankan melalui rekening } \\
\text { desa dengan didukung oleh bukti yang lengkap dan sah. } \\
\text { - Pelaksanaan kegiatan mengajukan Rencana Anggaran Biaya yang } \\
\text { diverivikasi oleh Sekertaris Desa } \\
\text { - Berdasarkan Rencana Anggaran Biaya, pelaksana kegiatan mengajukan } \\
\text { Surat Permintaan Pembayaran (SPP). }\end{array}$ \\
\hline Penatausahaan & $\begin{array}{l}\text { - Bendahara Desa melakukan pencatatan setiap pengeluaran dan penerimaan } \\
\text { dan melakukan tutup buku setiap akhir bulan secara tertib. } \\
\text { - Bendahara Desa mempertanggungjawabkan uang melalui laporan } \\
\text { pertanggungjawaban yang disampaikan setiap bulan kepada Kepala Desa } \\
\text { paling lambat tanggal } 10 \text { bulan berikutnya. }\end{array}$ \\
\hline Pelaporan & $\begin{array}{l}\text { - Sekertaris Desa menyusun laporan semester pertama dan Kepala Desa } \\
\text { menyampaikan kepada Bupati/Walikota pada akhir bulan Ju ni tahun } \\
\text { berjalan. } \\
\text { - Sekertaris Desa menyusun laporan semester akhir tahun dan Kepala Desa } \\
\text { menyampaikan kepada Bupati/Walikota paling lambat bulan Januari tahun } \\
\text { berikutnya. }\end{array}$ \\
\hline $\begin{array}{l}\text { Pertanggung- } \\
\text { jawaban }\end{array}$ & $\begin{array}{l}\text { - Sekertaris Desa menyusun laporan pertanggungjawaban } \\
\text { - Kepala Desa menyampaikan kepada Bupati/Walikota setiap akhir rahun } \\
\text { melalui Camat paling lambat } 1 \text { (satu) bulan setelah akhir tahun anggaran } \\
\text { - Laporan realisasi dan laporan pertanggungjawaban realisasi pelaksanaan } \\
\text { APBDesa diinformasikan ke masyarakat. }\end{array}$ \\
\hline
\end{tabular}

Sumber: Peraturan Menteri Dalam Negeri Nomor 113 Tahun 2014 tentang Pengelolaan Keuangan Desa

Populasi penelitian ini adalah seluruh Kepala Desa beserta aparat terkait serta laporan pertanggungjawaban APBDesa di Kecamatan Mare Kabupaten Bone yang terdiri dari 17 desa. Penarikan sampel dilakukan dengan teknik purposive sampling dengan kriteria; (1) Desa yang menerima dana ADD tertinggi; (2) Desa yang menerima dana ADD terendah; (3) Desa yang letaknya di Ibu Kota Kecamatan; (4) Desa yang letaknya terdekat dari Ibu Kota Kecamatan; (5) Desa yang letaknya terjauh dari Ibu Kota Kecamatan. Berdasarkan kriteria tersebut maka sampel yang terpilih dalam penelitian ini adalah: Desa Batu Gading, Desa Data, Desa Mario, Desa
Lappa Upang, dan Desa Kadai. Teknik pengumpulan data yang digunakan adalah kuesioner dan dokumentasi.

Analisis data menggunakan metode deskriptif komparatif dengan mengumpulkan, menyusun, menginterpretasikan, dan menganalisis data pengeloaan ADDD berdasarkan Peraturan Menteri Dalam Negeri Nomor 113 tahun 2014 tentang Pengelolaan Keuangan Desa di Kecamatan Mare Kabupaten Bone. Hasil analisis data dipersentasekan dengan menggunakan rumus yang dikemukakan oleh Arikunto (2006:202) sebagai berikut:

$$
\mathrm{IKK}=\frac{n}{\mathrm{~N}}
$$


Keterangan:

IKK = Indeks Kesesuaian Kasar

$\mathrm{n} \quad=$ Jumlah kode/jawaban yang

sama

$\mathrm{N} \quad=$ banyaknya objek yang diamati
Untuk menentukan pengelolaan ADD, hasil perhitungan IKK dibandingkan dengan standar sebagaimana dikemukakan oleh Arikunto (2006:246) sebagai berikut:

Tabel 2 Kualifikasi Persentase IKK

\begin{tabular}{c|c}
\hline Tingkat Persentase & Kualifikasi \\
\hline $76-100 \%$ & Sesuai \\
$57-75 \%$ & Cukup sesuai \\
$40-56 \%$ & Kurang sesuai \\
$0-39 \%$ & Tidak sesuai \\
\hline
\end{tabular}

Sumber: Arikunto (2006:246)

\section{HASIL DAN PEMBAHASAN \\ Gambaran Umum Pengelolaan ADD di \\ Kecamatan Mare Kabupaten Bone}

ADD pada 17 desa di Kecamatan Mare

Kabupaten Bone pada tahun 2016 tertuang dalam Peraturan Bupati Bone Nomor 3 Tahun 2016 tentang Besaran Dana Transfer Pada Setiap Desa di Kabupaten Bone. Secara umum, pengelolaan ADD dari 17 desa di Kecamatan Mare Kabupaten Bone dilaksanakan dengan tahapan yaitu: perencanaan, pelaksanaan, penatausahaan, pelaporan, dan pertanggungjawaban. Perencanaan ADD dilakukan dalam bentuk APBDesa berdasarkan RKPDesa tahun berkenaan disusun oleh Sekretaris Desa dan disampaikan kepada Kepala Desa yang kemudian dibahas bersama dengan badan Permusyarawatan Desa untuk di sepakati bersama paling lambat bulan Oktober tahun berjalan. Pelaksanaan ADD dilakukan berupa Tabel 3 Jumlah ADD di Kecamatan Mare Kabupaten Bone Tahun 2016

\begin{tabular}{cll}
\hline No & \multicolumn{1}{c}{ Nama Desa } & Jumlah \\
\hline 1 & Lappa Upang & Rp337.063.000,00 \\
2 & Batu Gading & Rp353.576.000,00 \\
3 & Lapasa & Rp344.781.000,00 \\
4 & Karella & Rp334.717.000,00 \\
5 & Mario & Rp338.576.000,00 \\
6 & Ujung Salangketo & Rp336.801.000,00 \\
7 & Cege & Rp326.141.000,00 \\
8 & Tellu Beccoe & Rp310.900.000,00 \\
9 & Kadai & Rp303.980.000,00 \\
10 & Tellongeng & Rp344.326.000,00 \\
11 & Mattampa Walie & Rp321.419.000,00 \\
12 & Data & Rp314.547.000,00 \\
13 & Sumaling & Rp325.285.000,00 \\
14 & Pattiro & Rp350.469.000,00 \\
15 & Lakukang & Rp326.116.000,00 \\
16 & Ujung Tanah & Rp340.189.000,00 \\
17 & Mattiro Walie & Rp329.188.000,00 \\
\hline
\end{tabular}

Sumber: Kantor Kecamatan Mare Kabupaten Bone, 2017. penerimaan dan pengeluaran desa dalam rangka pelaksanaan kewenangan desa dilaksanakan melalui rekening desa yang didukung oleh bukti yang lengkap dan sah. Penatausahaan ADD dilakukan oleh Bendahara Desa (dengan latar belakang pendidikan 80 persen adalah tamatan SMA dan 20 persen tamatan Strata Satu nonakuntansi) dengan mencatat setiap penerimaan dan pengeluaran dengan menggunakan buku kas umum, buku kas pembantu pajak dan buku bank serta melakukan tutup buku setiap akhir bulan secara tertib dan menyampaikan laporan pertanggungjawaban kepada Kepala Desa.

Jumlah ADD pada 17 desa di Kecamatan Mare Kabupaten Bone pada tahun 2016 yang tertuang dalam Peraturan Bupati Bone Nomor 3 Tahun 2016 tentang Besaran Dana Transfer Pada Setiap Desa di Kabupaten Bone, disajikan dalam tabel 3 di bawah ini. 
Pengelolaan ADD pada Lima Desa Sampel di
Kecamatan Mare Kabupaten Bone
Perencanaan ADD pada Lima Desa Sampel di
Kecamatan Mare Kabupaten Bone

Berdasarkan data dokumentasi dan hasil wawancara, perencanaan ADD pada lima desa sample di Kecamatan Mare Kabupaten Bone diawali dengan Musyawarah Perencanaan Pembangunan Desa (Musrembangdesa) untuk memperoleh RKPDesa yang disepakati. Setelah itu, Sekretaris Desa menyusun Rancangan Peraturan Desa tentang APBDesa untuk di sampaikan kepada Kepala Desa. Selanjutnya Kepala Desa menyampaikan Rancangan Peraturan Desa tentang APBDesa kepada BPD untuk disepakati sesuai aturan yang berlaku yaitu paling lambat bulan Oktober tahun berjalan. Melalui Camat Kecamatan Mare, Rancangan Peraturan Desa tentang APBDesa disampaikan kepada Bupati Kabupaten Bone. Apabila Bupati tidak memberikan hasil evaluasi dalam batas waktu 20 hari kerja maka Peraturan Desa tersebut berlaku dengan sendirinya, sebaliknya apabila Bupati menyatakan hasil evaluasi tidak sesuai dengan kepentingan umum dan peraturan peraturan perundang-undangan yang lebih tinggi Kepala Desa melakukan penyempurnaan paling lama 7 (tujuh) hari kerja sejak diterimanya hasil evaluasi.

\section{Pelaksanaan ADD pada Lima Desa Sampel di Kecamatan Mare Kabupaten Bone}

Berdasarkan data dokumentasi dan hasil wawancara, pelaksanaan ADD pada lima desa sampel Kecamatan Mare Kabupaten Bone dilakukan berdasarkan perencanaan yang sudah disusun secara matang dan terperinci sehingga semua penerimaan dan pengeluaran desa dalam rangka pelaksanaan kewenangan desa dilaksanakan melalui rekening kas desa dan dengan bukti yang lengkap dan sah. Mematuhi aturan yang berlaku, Pemerintah Desa tidak melakukan pungutan sebagai penerimaan desa selain yang ditetapkan dalam peraturan desa.

Dalam memenuhi kebutuhan operasional Pemerintah Desa, Bendahara Desa menyimpan uang dalam Kas Desa dengan jumlah tertentu. Pengeluaran desa yang mengakibatkan beban APBDesa tidak dilakukan oleh Pemerintah Desa apabila rancangan peraturan desa tentang APBDesa belum ditetapkan menjadi peraturan desa. Dalam menjalankan pemerintahan, apabila terjadi pembiayaan yang tak terduga Pemerintah Desa membuat Rincian Anggaran Biaya yang disahkan oleh Kepala Desa.
Pelaksana Kegiatan dalam mengajukan pendanaan untuk melaksanakan kegiatan dengan menyertakan dokumen Rencana Anggaran Biaya yang telah diverifikasi oleh Sekretaris Desa dan disahkan oleh Kepala Desa. Sebagai pihak yang bertanggungjawab terhadap tindakan pengeluaran, Pelaksana Kegiatan menggunakan buku pembantu kas kegiatan sebagai pertanggungjawaban. Berdasarkan Rencana Anggaran Biaya, Pelaksana Kegiatan mengajukan Surat Permintaan Pembayaran (SPP) kepada Kepala Desa setelah barang dan jasa diterima, dengan melampirkan pernyataan tanggungjawab belanja dan bukti transaksi.

Sekretaris Desa juga melakukan kewajibannya atas pengajuan pelaksanaan pembayararan, yaitu: (1) Meneliti kelengkapan permintaan pembayaran; (2) Menguji kebenaran perhitungan tagiahan atas beban APBDesa yang tercantum dalam permintaan pembayaran; (3) Menguji ketersediaan dana untuk kegiatan yang dimaksud; (4) Menolak pengajuan permintaan pembayaran apabila tidak memenuhi persyaratan yang ditetapkan. Setelah Sekretaris Desa memverifikasi, Kepala Desa menyetujui permintaan pembayaran dan Bendahara Desa melakukan pembayaran dan mencatat sebagai pengeluaran. Bendahara Desa melakukan pungutan potongan dan pajak yang kemudian disetor ke rekening kas negara. Pengadaan barang/jasa dilakukan sesuai dengan Peraturan Bupati Bone yang berpedoman pada ketentuan peraturan perundang-undangan.

Penatausahaan ADD pada Lima Desa Sampel di Kecamatan Mare Kabupaten Bone

Berdasarkan data dokumentasi dan hasil wawancara, penatausahaan ADD pada lima desa sampel di Kecamatan Mare Kabupaten Bone dilakukan oleh Bendahara Desa. Sesuai tugasnya Bendahara Desa melakukan pencatatan secara sistematis dan kronologis terhadap transaksitransaksi keuangan yang terjadi baik berupa penerimaan maupun pengeluaran dengan menggunakan: (1) Buku Kas Umum, dengan format: nomor, tanggal, kode rekening, uraian, penerimaan, pengeluaran, nomor bukti, jumlah pengeluaran komulatif, dan saldo; (2) Buku Kas Pembantu Pajak, dengan format; nomor, tanggal, pemotongan, penyetoran, dan saldo; (3) Buku Bank, dengan format: nomor, tanggal, uraian transaski, bukti transaksi, setoran, bunga bank, penarikan, pajak, biaya administrasi, dan saldo. Setelah melakukan pencatatan terhadap seluruh transaksi, Bendahara Desa melakukan tutup buku setiap akhir bulan. 
Pertanggungjawaban uang dibuat oleh Bendahara Desa dengan membuat Laporan Pertanggungjawaban pengeluaran dan penerimaan dengan format; nomor, kode rekening, uraian, dan jumlah. Laporan Pertanggungjawaban tersebut dibuat berdasarkan arus uang yang masuk dan arus uang yang keluar, serta diverifikasi oleh Sekretaris Desa sebelum disampaikan kepada Kepala Desa setiap bulannya sebelum tanggal 10 bulan berikutnya.

\section{Pelaporan ADD pada Lima Desa Sampel di Kecamatan Mare Kabupaten Bone}

Berdasarkan data dokumentasi dan hasil wawancara, pelaporan ADD di pada lima desa sampel di Kecamatan Mare Kabupaten Bone dilakukan oleh Kepala Desa dengan menyampaikan laporan pertanggungjawaban realisasi pelaksanaan APBDesa kepada Bupati berupa: (1) Laporan semester pertama, dan (2) Laporan semester akhir tahun. Laporan semester pertama disampaikan tepat waktu, yaitu pada akhir bulan Juli tahun berjalan. Laporan semester akhir tahun disampaikan tepat waktu, yaitu pada akhir bulan Januari tahun berikutnya. Kedua laporan tersebut dibuat oleh Kepala Desa, Sekretaris Desa, dan Bendahara Desa.

\section{Pertanggungjawaban ADD pada Lima Desa} Sampel di Kecamatan Mare Kabupaten Bone

Berdasarkan data dokumentasi dan hasil wawancara, pertanggungjawaban ADD pada lima desa sampel di Kecamatan Mare Kabupaten Bone disampaikan kepada Bupati di akhir tahun anggaran oleh Kepala Desa berupa realisasi pelaksanaan APBDesa. Laporan pertanggungjawaban realisasi pelaksanaan APBDesa tersebut terdiri dari: (1) Pendapatan; (2) Belanja; dan (3) Pembiayaan yang ditetapkan dengan Peraturan Desa. Laporan realisasi dan laporan pertanggungjawaban realisasi APBDesa diinformasikan kepada masyarakat dan disampaikan kepada Bupati tepat waktu, yaitu paling lambat 1 bulan setelah akhir tahun anggaran berkenaan.

Berdasarkan data dokumentasi dan hasil wawancara pada lima desa sampel yang dibahas di atas, hasil analisis penerapan pengelolaan ADD di Kecamatan Mare Kabupaten Bone disajikan dalam tabel 4. Berdasarkan analisis data dalam tabel 4 tersebut yang dilakukan menggunakan metode deskriptif komparatif dengan mengacu pada pengukuran variabel yang terdiri dari 63 indikator sebagaimana dirinci dalam Pasal 20 sampai dengan Pasal 43 Peraturan Menteri Dalam Negeri Nomor 113 Tahun 2014 tentang Pengelolaan Keuangan
Desa, hasilnya kemudian dipersentasekan dengan menggunakan rumus yang dikemukakan oleh Arikunto (2010:246) sebagai berikut:

$$
\begin{aligned}
& \text { IKK }=\frac{n}{\mathrm{~N}} \\
& \text { Keterangan: } \\
& \mathrm{IKK}=\text { Indeks Kesesuaian Kasar } \\
& \mathrm{n}=\text { Jumlah Kode/Jawaban } \\
& \text { yang sama } \\
& \mathrm{N}=\text { Banyaknya Objek yang } \\
& \text { diamati } \\
& \text { Berdasarkan rumus tersebut diperoleh } \\
& \text { nilai IKK }=\frac{63}{63} \text { X } 100 \%=100 \% .
\end{aligned}
$$

Berdasarkan kualifikasi persentase IKK yang dikemukakan oleh Arikunto (2010: 246) tingkat persentase 76-100 persen dikualifikasikan "sesuai". Dengan demikian, dapat disimpulkan bahwa pengelolaan ADD di Kecematan Mare Kabupaten Bone telah sesuai dengan Peraturan Menteri Dalam Negeri Nomor 113 Tahun 2014 tentang Pengelolaan Keuangan Desa.

\section{Pembahasan}

Berdasarkan hasil penelitian dan pembahasan yang dikemukakan dapat disimpulkan bahwa pengelolaan ADD yang meliputi: perencanaan, pelaksanaan, penatausahaan, pelaporan, dan pertanggungjawaban pada lima desa di Kecamatan Mare Kabupaten Bone yakni: Desa Batu Gading, Desa Data, Desa Mario, Desa Lappa Upang, dan Desa Kadai telah sesuai dengan Peraturan Menteri Dalam Negeri Nomor 113 Tahun 2014 tentang Pengelolaan Keuangan Desa. Indikator pengelolaan ADD sejumlah 63 indikator, seluruhnya telah dilaksanakan di Kecamatan Mare Kabupaten Bone.

Hasil penelitian ini sejalan dengan penelitian Apriliani (2014) yang menunjukkan bahwa pada tahap perencanaan, pelaksanaan, dan pertanggungjawaban ADD di Desa Kedungrejo Kecamatan Muncar Kabupaten Banyuwangi tahun 2013 telah memenuhi prosedur yang berlaku. Namun masalah yang muncul adalah kurangnya koordinasi antar anggota Tim Pelaksana ADD serta penyampaian laporan pertanggungjawaban yang terlambat. Penelitian lain oleh Thomas (2012) yang bertujuan untuk mengetahui pengelolaan ADD dan hambatan-hambatan yang dihadapi oleh pemerintah desa dalam pengelolaan ADD di Desa Sebawang Kecamatan Sesayap Kabupaten Tana Tidung menunjukkan bahwa 30 persen dari dana ADD bisa berjalan sesuai dengan petunjuk namun 70 persen dari ADD berjalan kurang 
optimal karena lebih direalisasikan pada pembangunan fisik dan pengadaan barang. Hambatan yang dihadapi dalam proses pengelolaan ADD adalah rendahnya sumber daya manusia aparat desa dan kurangnya koordinasi. Penelitian sebelumnya oleh Subranto (2009) yang bertujuan untuk mendeskripsikan akuntabilitas pengelolaan ADD menunjukkan bahwa untuk perencanaan dan pelaksanaan kegiatan ADD sudah menampakkan adanya pengelolaan yang akuntabel dan transparan. Demikian pula dalam pertanggungjawaban dilihat secara hasil fisik sudah menunjukkan pelaksanaan yang akuntabel dan transparan. Namun dari sisi administrasi masih diperlukan adanya pembinaan lebih lanjut, karena belum sepenuhnya sesuai dengan ketentuan. Kendala utamanya adalah belum efektifnya pembinaan aparat pemerintahan desa dan kompetensi sumber daya manusia, sehingga masih memerlukan pendampingan dari aparat pemerintah daerah secara berkelanjutan.

\section{SIMPULAN DAN SARAN}

Berdasarkan hasil penelitian dan pembahasan yang dikemukakan dapat disimpulkan bahwa pengelolaan ADD yang meliputi: perencanaan, pelaksanaan, penatausahaan, pelaporan, dan pertanggungjawaban pada lima desa di Kecamatan Mare Kabupaten Bone telah sesuai dengan Peraturan Menteri Dalam Negeri Nomor 113 Tahun 2014 tentang Pengelolaan Keuangan Desa. Indikator pengelolaan ADD sejumlah 63 indikator, seluruhnya telah dilaksanakan di Kecamatan Mare Kabupaten Bone. Kendala yang dihadapi adalah masih kurangnya kerjasama antara aparat desa, masyrakat, dan pihak terkait dalam pengelolaan ADD; serta masih kurangnya pemahaman Bendahara Desa dalam pengelolaan ADD disebabkan latar belakang pendidikan dan keahlian yang dimiliki sehingga harus didampingi oleh Tim Pendamping Kecamatan.

Berdasarkan kesimpulan di atas, dikemukakan beberapa saran sebagai dasar pemikiran dan pertimbangan untuk melakukan tindakan perbaikan dan pengembangan pengelolaan ADD dimasa mendatang, yakni: (1) Kepada aparat desa, masyarakat, dan seluruh pihak yang terkait di Kecamatan Mare Kabupaten Bone disarankan agar dapat lebih meningkatkan kerjasama dalam pengelolaan ADD; (2) Kepada Kepala Desa di Kecamatan Mare Kabupaten Bone disarankan kiranya mengangkat Bendahara Desa yang memiliki latar belakang pendidikan dan keahlian pada bidang akuntansi; (3) Kepada Pemerintah Kecamatan Mare Kabupaten Bone disarankan melaksanakan pelatihan yang memadai kepada seluruh aparat desa terkait teknis pengelolaan ADD dan menyediakan media informasi mengenai pengelolaan ADD yang mudah diakses oleh seluruh aparat desa pada khusunya dan seluruh masyarakat pada umumnya. ${ }^{\circledR}$

\section{DAFTAR RUJUKAN}

Aprialiani, G. S. 2014. Akuntabilitas Pengelolaan ADD di Desa Kedongrejo Kecamatan Muncar Kabupaten Banyuwangi. Jurnal. Tidak Diterbitkan. Jember: Fakultas Ekonomi Universitas Jember.

Peraturan Bupati Bone Nomor 13 Tahun 2015 tentang Tata Cara Pembagian Dana Transfer Desa di Kabupaten Bone.

Peraturan Bupati Bone Nomor 14 Tahun 2015 tentang Besaran Dana Transfer Pda Setiap Desa di Kabupaten Bone.

Peraturan Bupati Bone Nomor 15 Tahun 2015 tentang Pedoman Penyusunan Anggaran Pendapatan dan Belanja Desa.

Peraturan Menteri Dalam Negeri Republik Indonesia Nomor 133 Tahun 2014 tentang Pedoman Pengelolaan Keuangan Desa.

Peraturan Pemerintah Republik Indonesia Nomor 43 Tahun 2014 Tentang Peraturan Pelaksanaan Undang-Undang Indonesia Nomor 6 tahun 2014 Tentang Desa.

Subranto, A. 2009. Akuntabilitas Dana Desa (Studi Kasus Pengelolaan ADD di DesaDesa Dalam Wilayah Kecamatan Tlogomulyo Kabupaten Temanggung Tahun 2008). Tesis. Tidak Diterbitkan. Semarang: Pascasarjana Universitas Dipenegoro.

Sugiyono. 2014. Metode Penelitian Kuantitatif, Kualitatif dan R\&D: Bandung: Alfabeta.

Thomas. 2013. Pengelolaan ADD Dalam Upaya Meningkatkan Pembangunan di Desa Sebawang Kecamatan Sesayap Kabupaten Tana Tidung. Jurnal. Tidak Diterbitkan. Tana Tidung: Fakultas Ilmu Sosial dan Ilmu Politik Universitas Mulawarman.

Undang-Undang Republik Indonesia Nomor 6 tahun 2014 tentang Desa. 